\title{
International Workshop
}

Protected Areas as Tools for Regional Development -

Perspectives for Research and Management

13-15 October 2011

Saint-Pierre-de-Chartreuse, Parc Naturel Régional de la Chartreuse, French Alps

Programme, Registration (until 31.8.2011)

http://www.iscar-alpineresearch.org/workshop2011/

Contact: iscar@scnat.ch

\section{Organizing institutions}

ISCAR - International Scientific Committee on Research in the Alps: Axel Borsdorf, Thomas Scheurer

Parc Naturel Régional de la Chartreuse: Gérard Hanus

ALPARC - Alpine Network of Protected Areas: Guido Plassmann

NeReGro - Regional Development and Protected Areas Working Group: Thomas Hammer, Ingo Mose, Dominik Siegrist, Norbert Weixlbaumer

\section{Background situation}

Protected areas such as national parks, biosphere reserves, UNESCO world heritage sites and regional nature parks have functions beyond nature and landscape protection in a narrow sense, e.g. in the field of environmental education, sustainable use of natural resources, marketing of local quality products or promotion of nature based tourism. According to recent research, protected areas can make various contributions to regional development by their existence and activities. Protected areas are increasingly seen as virtual catalysts or even motors for regional development. However, this view implies risks due to the latent danger of nature and landscape protection on the one hand and regional development on the other hand being played off against each other and hence blocking each other. Therefore one objective should be creating synergies between protection and use - that is, enable sustainable regional development.

The workshop addresses the state of the art as well as gaps in research and perspectives of future research indicated by the present debate about the integration of nature and landscape protection and regional development in protected areas and their adjacent regions. What are major findings of recent research, what are obvious research gaps and what are essential challenges for future research? - Researchers and protected area staff in charge of research as well as practitioners discuss and mutually identify themes and focal points for future research.

\section{Aims of the workshop}

The overriding aim of the workshop is to identify and address perspectives for research in the field of protected areas and regional development and make major contributions to the identification of new research themes in this area.

In detail the aims are

- to gather the present state of research (e.g. previous projects, major findings) regarding protected areas and regional development and mostly addressed issues and topics ("state of the art"),

to identify major gaps of knowledge and challenges for future research related to these issues and topics,

- to identify topics and questions that have been neglected or overlooked so far,

to name thematic focal points of a research agenda both visionary and feasible,

to foster exchange among researchers as well as between researchers and practitioners regarding knowledge, deficits and perspectives,

to identify possible demand for cooperation among researchers as well as between researchers and practitioners,

to improve concrete forms of cooperation between researches and practitioners,

to initiate new research activities in the area of identified research-gaps.

Target audience

The workshop is aimed at researchers and experts from related areas of practice (e.g. park administration, regional policy, tourism, agriculture) who deal with the subject of protected areas and regional development. 